The Geographical Journal of Nepal

Vol. 13: 201-213, 2020

Doi: http://doi.org/10.3126/gjn.v13i0.28159

Central Department of Geography,

Tribhuvan University, Kathmandu, Nepal

\title{
Major hazards and disaster response capacity of Dadeldhura district
}

\author{
* Raj Kumar Pariyar and Basanta Kumar Neupane \\ (*Corresponding Author: rajpariyar2012@gmail.com)
}

Received: 26 October 2019; Accepted: 15 January 2020; Published: March 2020

\begin{abstract}
This study endeavours to explore the major hazards and the response capacity to disaster of Dadeldhura district. It used checklist to collect information on hazard ranking and capacity assessment. Similarly, key informant interview conducted with the key portfolios and members of district disaster management committee and Nepal Red Cross Society. Likewise, one focus group discussion was conducted with the purpose to draw insights of major disaster and capacity. Moreover, a district disaster preparedness plan was reviewed to understand the context of hazard and response. The major hazards of Dadeldhura district are landslide, flood, hailstone, fire, endemic, drought, thunderbolt and earthquake. Among all hazards landslide is in the first and flood is in the second rank based on damage and loss of physical property and livelihood. According to the district disaster preparedness and response plan, 2075, nine clusters have formed and updated emergency response plan for effective action in Dadeldhura. Among the nine clusters, this study only includes the search and rescue cluster to assess disaster response capacity. It has been found that out of nine clusters, search and rescue cluster seems progressive. However, the number of search and rescue trained people need to be increased. Likewise, the facility of ambulance and fire brigades need to extend in each rural municipality. Existing ambulance also need to be repaired and maintained regularly. The existing capacity is not enough to disaster response so, new efforts need to have been updated by DPRP with new activities to enhance the capacity.
\end{abstract}

Key-words: Hazard, disaster, disaster response, emergency, search and rescue, capacity.

\section{Introduction}

Hazard is a dangerous phenomenon, substance, human activity or condition that may cause loss of life, injury or other health impacts, property damage, loss of livelihoods 
and services, social and economic disruption, or environmental damage (UNISDR, 2009). Disaster is a serious disruption of the functioning of a community or a society involving widespread human, material, economic or environmental losses and impacts, which exceeds the ability of the affected community or society to cope using its own resources (MoHa, 2072). Disasters are often described as a result of the combination of the exposure to a hazard, the conditions of vulnerability that are present, and insufficient capacity or measures to reduce or cope with the potential negative consequences. Disaster impacts may include loss of life, injury, disease and other negative effects on human physical, mental and social well-being, together with damage to property, destruction of assets, loss of services, social and economic disruption and environmental degradation (UNISDR, 2009). When a large number of population exposed to a hazard are killed, injured, the event is termed disaster. Thus, a disaster is a realization of hazard, although there is no universally agreed definition regarding the scale on which loss has to occur in order to qualify as a disaster (Proaga,2014).

Disaster preparedness and response include a range of activities to protect communities, property and the environment (Koka and et al., 2018). Disaster response is similar with emergency response. Emergency response is a set of services that are provided to the disaster affected people as per their immediate need in face of a probable natural or human induced disaster to occur or immediately after an event of disaster. The aim of disaster response activities is to ensure the security of lives and properties of the disaster affected people as well as to reduce the sufferings of the disaster victims. Usually emergency response is initiated for short term period. Major disaster response activities are: dissemination of early warning, search and rescue operation, evacuation, first aid, shelter management, relief distribution, valuable information sharing related to life and asset saving etc. (Volunteers guideline, 2017). Emergencies can be on any scale, affecting a single household or a local community, causing disruption at a national or even global level. Emergencies are defined as life threatening situations which put people at risk of death or severe deterioration in their health status or living conditions, and which have the potential to out-strip the normal coping capacity of the individual, family, community and state support systems. Emergencies may affect men and women differently, and they in turn have differing ways of coping with emergencies (IFRC, Emergency response policy, 2017). The capacity includes strengths and resources available within a community such as the relevant institutions, social infrastructures, and skilled manpower useful for disaster management. A livelihood is considered as sustainable when it can cope with and recover from stresses and shocks (e.g. natural disasters, conflicts, epidemics etc. This study endeavours to explore the major hazards and the response capacity of Dadeldhura disaster. 


\section{Methodology}

Checklist was used to collect major hazards and capacities of the district. District disaster management committee was carefully observed and data collected on hazard ranking, capacity assessment and to assess the trained human resources on response and preparedness. Key informant interviews were conducted with the key portfolios and members of district disaster management committee (DDMC) and Nepal Red Cross Society (NRCS) district chapter. Likewise, one focus group discussion was conducted with the participation of DDMC members. Focus group discussions aimed to draw the insights of major disaster and coping abilities, as well as human knowledge, skills and collective attributes such as social relationships, leadership and management. The collected different data were tabulated and analysed in Microsoft Excel software. The district disaster preparedness plan (DPRP) developed by DDMC was reviewed to understand the context of district disaster response capacity.

\section{Study area}

Dadeldhura district lies in Sudur Pashchim province which spreads $28^{0} 59^{\prime \prime}$ to $29^{\circ} 26^{\prime \prime}$ North latitude and $80^{\circ} 12^{\prime \prime}$ to $80^{\circ} 74 "$ East longitude (DEO, 2019). The district, with an area of 1,538 sq. km (DEO, 2019) is divided into two municipalities and five rural municipalities. The district characterised by two physiographic regions $28.2 \%$ of areas under Churia hills and duns and $71.8 \%$ areas under middle mountains (Ghimire and Basnet, 2015). Elevation of the district ranges from 305 meter in the south to 2039 meter in the north above mean sea level. It has 27,045 households with a total population of 142,094 (male $66,656 \&$ female 75,538 ). Literacy rate in the district is $53.43 \%$ (women's literacy rate is $33.9 \%$ ). The district is well served by road network. Dadeldhura is the gateway to various hilly districts of the region such as Accham, Doti, Baitadi, Bajura, etc. Due to its strategic location, the district has a potential to be a regional hub. The major rivers are Seti and Mahakali. Chama, Bhungra, Sakayal, Rangun, Sadhani, Raduwa, Rupali, Shirsha, Puntura are the major small rivers. In addition, Alital and Wadapathi are the famous ponds. There are water falls in Rasail in Rupal and Kumadgau in Gangkhet (DEO, 2019). This district is vulnerable from the perspective of hazards. Each year in average 1000 families are affected by various disasters including flood, landslide and fire. Similarly, this district is also affected by diarrhoea and transmitted diseases. This is vulnerable district in terms of earthquake as well (DPRP, 2075). 


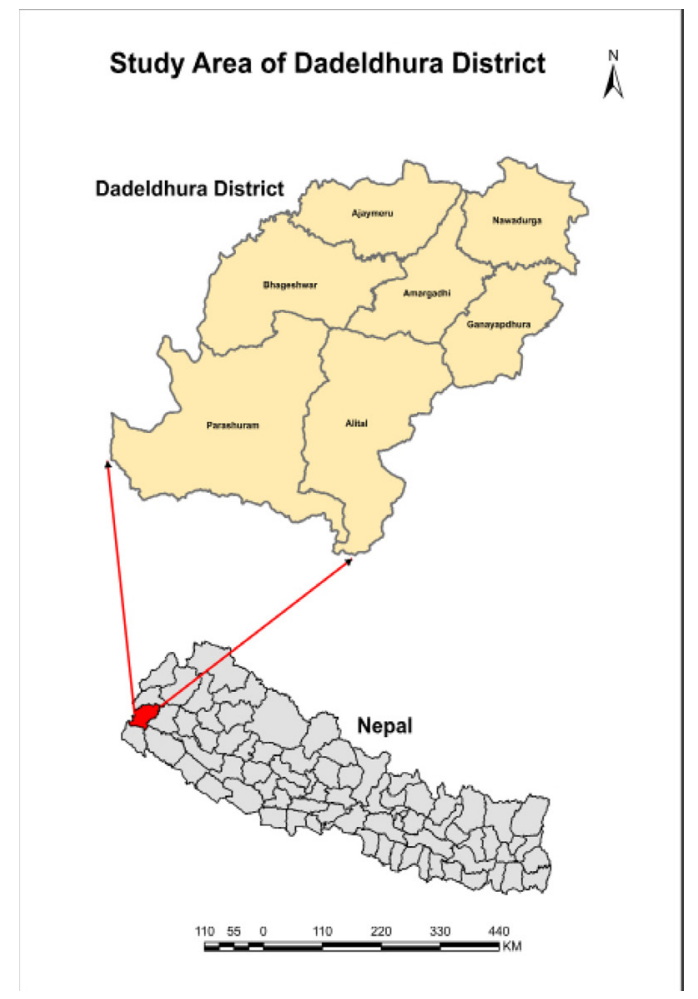

Figure 1: Location map of Dadeldhura district

\section{Results and discussion}

\section{Disaster history of Dadeldhura district}

This district might have been stricken by various disasters for ages. However, as per the available data from Ministry of Home Affairs, Nepal (2019). Dadeldhura district has been suffering from multidisasters since 1972. As per the number of deaths, epidemic is the first ranked disaster. Landslide is the second by where 27 people were lost, one missed, and 3,224 families were affected. Similarly, 38 households were fully damaged, and 39 households were partially damaged. Flood is another devastated disaster that caused 21 human being lost, five missing and 4,423 families were affected. Moreover, 73 houses were fully damaged, and 60 houses are partially damaged. Road accident, fire, thunderbolt, cold wave also affected the people and assets (Table 1). Thus, from 1972 to 2019 during the period of 47 years 123 people have been lost their life. Likewise, six people have been missed, 11,837 families were affected, 249 people were injured, 187 houses have been fully damaged, and 742 houses have been partially damaged. There has been a huge human and economic loss from multiple disasters. 
Table 1: Effect of disaster in Dadeldhura (1972-2019)

\begin{tabular}{|l|r|r|r|r|r|r|r|}
\hline \multicolumn{1}{|c|}{ Disaster } & $\begin{array}{c}\text { Total } \\
\text { Death }\end{array}$ & $\begin{array}{c}\text { Missing } \\
\text { People }\end{array}$ & $\begin{array}{c}\text { Affected } \\
\text { Family }\end{array}$ & $\begin{array}{c}\text { Estimated } \\
\text { Loss }\end{array}$ & Injured & $\begin{array}{c}\text { Fully } \\
\text { Damaged } \\
\text { House }\end{array}$ & $\begin{array}{c}\text { Partially } \\
\text { Damaged } \\
\text { House }\end{array}$ \\
\hline Epidemic & 42 & 0 & 1,131 & 0 & 179 & 0 & 0 \\
\hline Landslide & 27 & 1 & 3,224 & $3,00,000$ & 14 & 38 & 39 \\
\hline Flood & 21 & 5 & 4,423 & 0 & 1 & 73 & 60 \\
\hline Accident & 8 & 0 & 0 & 0 & 0 & 0 & 0 \\
\hline Fire & 7 & 0 & 291 & $16,16,88,443$ & 5 & 74 & 32 \\
\hline Thunderbolt & 7 & 0 & 26 & 0 & 46 & 0 & 2 \\
\hline Cold Wave & 4 & 0 & 30 & 0 & 0 & 0 & 0 \\
\hline Snow Storm & 3 & 0 & 0 & 0 & 0 & 0 & 2 \\
\hline Other & 4 & 0 & 2,712 & $26,81,500$ & 4 & 2 & 607 \\
\hline Total & 123 & 6 & 11,837 & $16,46,69,943$ & 249 & 187 & 742 \\
\hline
\end{tabular}

Source: Ministry of Home Affair, Nepal, 2019

\section{Major hazards}

Hazards arise from a variety of geological, meteorological, hydrological, oceanic, biological, and technological sources, sometimes acting in combination. In technical settings, hazards are described quantitatively by the likely frequency of occurrence of different intensities for different areas, as determined from historical data or scientific analysis. Hazards are divided in biological hazard, geological hazard, hydrometeorological hazard, natural hazard, socionatural hazard and technological hazard (UNISDR, 2009).

Table 2: Hazard ranking of Dadeldhura district

\begin{tabular}{|l|l|l|l|l|l|l|l|l|r|}
\hline Hazards & $\begin{array}{l}\text { Land- } \\
\text { slide }\end{array}$ & Flood & $\begin{array}{l}\text { Hail- } \\
\text { stone }\end{array}$ & Fire & $\begin{array}{l}\text { En- } \\
\text { demic }\end{array}$ & Drought & $\begin{array}{l}\text { Thunder- } \\
\text { bolt }\end{array}$ & $\begin{array}{l}\text { Earth- } \\
\text { quake }\end{array}$ & Score \\
\hline $\begin{array}{l}\text { Land- } \\
\text { slide }\end{array}$ & & $\begin{array}{l}\text { Land- } \\
\text { slide }\end{array}$ & $\begin{array}{l}\text { Land- } \\
\text { slide }\end{array}$ & $\begin{array}{l}\text { Land- } \\
\text { slide }\end{array}$ & $\begin{array}{l}\text { Land- } \\
\text { slide }\end{array}$ & Landslide & Landslide & Landslide & 7 \\
\hline Flood & & & Flood & Flood & Flood & Flood & Flood & Flood & 6 \\
\hline Hailstone & & & & $\begin{array}{l}\text { Hail- } \\
\text { stone }\end{array}$ & $\begin{array}{l}\text { Hail- } \\
\text { stone }\end{array}$ & Hailstone & Hailstone & Hailstone & 5 \\
\hline Fire & & & & & Fire & Fire & Fire & Fire & 4 \\
\hline Endemic & & & & & & Endemic & Endemic & Endemic & 3 \\
\hline Drought & & & & & & & Drought & Drought & 2 \\
\hline $\begin{array}{l}\text { Thun- } \\
\text { derbolt }\end{array}$ & & & & & & & & $\begin{array}{l}\text { Thunder- } \\
\text { bolt }\end{array}$ & 1 \\
\hline $\begin{array}{l}\text { Earth- } \\
\text { quake }\end{array}$ & & & & & & & & & \\
\hline Ranking & First & Second & Third & Fourth & Fifth & Sixth & Seventh & Eighth & \\
\hline
\end{tabular}

Source: DPRP, 2019 
As per the District Disaster Preparedness and Response Plan (DPRP) 2019, the major hazards of Dadeldhura district are landslide, flood, hailstone, fire, endemic, drought, thunderbolt and earthquake. Among all hazards landslide is in the first and flood is in the second ranked based on damage and loss of physical property and livelihood (Table 2). Both natural and anthropogenic factors contribute to landslides. Natural factors may be subdivided into inherent and external factors. Inherent factors include geological formation and structure, slope, aspect, land use, land cover and groundwater conditions. External factors include seismic waves and rainfall. Anthropogenic factors include human interventions like deforestation, improper land use, unplanned construction, and unplanned mining (Nepal Disaster Report, 2009).

Earthquake is in the eighth rank in Dadeldhura district. But Nepal's proximity to earthquake hazards is mainly due to her young and fragile geology. Haphazard and unplanned settlements and poor construction practice are the other reasons that have made her highly vulnerable to earthquake impacts. Earthquake threats the entire country all the time and it is poised for a mega disaster for which scientists are forecasting with a high probability of its occurrence anytime anywhere in the region (Nepal Disaster Report, 2015). So, the plan needs to be developed that the earthquake is in the first rank (LDCRP draft guideline, 2074).

\section{Disaster response capacity}

The sustainable livelihood framework (DFID, 1999) expresses strengths and capacities of people in terms of their livelihood assets namely human, natural, financial, social, physical and natural capitals. Capacity may include infrastructure and physical means, institutions, societal coping abilities, as well as human knowledge, skills and collective attributes such as social relationships, leadership and management. Capacity may also be described as capability. Capacity assessment is a term for the process by which the capacity of a group is reviewed against desired goals, and the capacity gaps are identified for further action (UNISDR, 2009). Coping capacity also depends on adequate household assets and supportive social and governance relations and can be thought of as a component of wider capacity development for disaster risk reduction (DFID, 2004).

The National Disaster Response Framework (NDRF) 2013 has been amended in Nepal. The NDRF, 2013 is a guideline for disaster response in Nepal. The amendment was in line with the federal governance system on disaster risk reduction for mobilization of national level resources. The amendment supports to implement the disaster risk reduction and management act 2074 (NDRF, 2019). 
Dadeldhura district has identified nine clusters for the disaster response. The thematic area of the clusters are: i) information, communication and coordination ii) search and rescue iii) emergency shelter and non-food materials iv) health and nutrition v) drinking water, sanitation and hygiene vi) food security and livelihood vii) emergency education viii) rehabilitation, reconstruction and logistics management and ix) protection (DPRP, 2019). Out of these nine thematic areas for the disaster response, this study only tries to analyse the search and rescue thematic area.

\section{Search and rescue}

The capacity building on search and rescue is very crucial for saving lives of people. The emergency fund, if established, can be used to provide the rescue, relief and rehabilitation materials and distribute the flood affected people during the emergency situation (Osti, 2008). Search techniques focus on where victims are likely to be located and areas of entrapment. Areas of entrapment inside damaged structures are called voids; they include spaces that victims get into to protect themselves (under desks, in bathtubs, in cupboards). When potential areas of entrapment have been identified and the potential number of victims estimated, search operations begin. Initially, searchers call out, requesting victims to identify their location, following a systematic search pattern.

Trapped victims are removed and given medical aid as necessary. Triage may be used to prioritize assistance for those who need it most. Before removing victims, it is often necessary to move or stabilize debris. Victims may be able to walk to safety places themselves, or may be removed using lifts, drags, or carries. Removal of victims is designed to avoid further injury (UNHCR, 2019).

\section{Human resource for search and rescue}

Human resource for search and rescue is the first essential part for disaster response. But a report of Hyogo Framework for Action clearly identified the challenges. The most common challenges identified are: lack of pragmatic DRM Act, relief and response centric DRM activities, a lack of dedicated high-level DRM institutions. Moreover, the report has also included weak implementation of activities, poor monitoring and evaluation mechanisms. Inadequate trained human resource is one of the challenges at all levels and ineffective information management system (NDR, 2017). 
Table 3: Human resource for search and rescue in Dadeldhura

\begin{tabular}{|c|c|c|c|}
\hline Sector & Agency & $\begin{array}{c}\text { No. of trained } \\
\text { human resources }\end{array}$ & Places \\
\hline Search and rescue & $\begin{array}{l}\text { NRCS and } \\
\text { municipality }\end{array}$ & 450 & $\begin{array}{l}\text { NRCS and Parshuram } \\
\text { municipality, Alital, Nawadurga } \\
\text { and Ganyapdhura rural } \\
\text { municipality }\end{array}$ \\
\hline Search and rescue & Nepal police & 40 & $\begin{array}{l}\text { District police and area police } \\
\text { office }\end{array}$ \\
\hline Search and rescue & $\begin{array}{l}\text { Armed police } \\
\text { force (APF) } \\
\end{array}$ & 25 & \\
\hline Search and rescue & Nepal army & As per need & \\
\hline First AID & $\begin{array}{l}\text { NRCS and } \\
\text { municipality }\end{array}$ & 500 & $\begin{array}{l}\text { different chapters of NRCS and } \\
\text { Parshuram municipality, Alital, } \\
\text { Nawadurga and Ganyapdhura } \\
\text { rural municipality }\end{array}$ \\
\hline Total & & 1,015 & \\
\hline
\end{tabular}

Source: DPRP, 2019

There are total 1,015 trained human resources on search and rescue. Nepal Red Cross Society (NRCS) and all municipalities have 450 trained human resources. These trained human resources include community action for disaster response (CADRE), district disaster response team (DDRT) and national disaster response team (NDRT). Human resource seems dispersed in NRCS district chapter, sub-chapter and in some municipalities such as Amargadi and Parshuram. Likewise, in some rural municipalities such as Alital, Nawadurga and Ganyapdhura. The search and rescue related human resources are generally provided by security forces. Despite the lack of enough search and rescue equipment and resources, security forces played a significant role in search and rescue and relief works (Nepal Disaster Report 2015).

In Dadeldhura district, Nepal Police and APF have 40 and 25 trained human resource respectively (Table 2). Nepal Army can provide human resource as per the need at the time of disaster response. The search and rescue also include the process of locating and recovering disaster victims and the application of first aid and basic medical assistance as may be required (Nepal Disaster Report, 2015). So, for the basic first aid service, Dadeldhura district has 500 trained human resources on first aid. These trained resources have based in different chapters of NRCS and Parshuram municipality, Alital, Nawadurga and Ganyapdhura rural municipalities. It seems that there is no good coordination between community and security forces for search and rescue. In addition, there is not the separate fund to recover first aid kits after used up in emergency. 


\section{Search and rescue materials}

Search and rescue are impossible without necessary materials in disaster response. As per the experience, search and rescue materials are always lack of in Nepal. search and rescue material include life jacket, helmet, boot, gloves, glass, pick, axe, spade, first aid kits, crowbar, shovel, stretcher etc. Dadeldhura district have various sets of search and rescue materials. Nepal Army, Nepal Police, Armed Police Force have their separate search and rescue materials. Likewise, district emergency operation centre (DEOC)has search and rescue materials (Table 4).

Table 4: Search and rescue material in Dadeldhura district

\begin{tabular}{|c|c|c|c|c|}
\hline Material & Nepal army & Nepal police & $\overline{\mathbf{A P F}}$ & DEOC \\
\hline Rescue jacket & 8 & 57 & 8 & 3 \\
\hline Life jacket & & & & $\overline{10}$ \\
\hline Helmet & 15 & 23 & 8 & 4 \\
\hline Boot & 12 & 12 & 8 & 1 \\
\hline Pick & 7 & & 5 & 2 \\
\hline Axe & 6 & 10 & 5 & 1 \\
\hline Spade & 7 & 25 & 4 & \\
\hline First aid kits & 2 & & 1 & 10 \\
\hline Crowbar & 5 & 34 & 5 & 3 \\
\hline Shovel & 5 & 34 & 3 & 3 \\
\hline Tube & 3 & 8 & 1 & \\
\hline Stretcher & & 24 & 1 & 1 \\
\hline $\begin{array}{l}\text { folding stretcher3, } \\
\text { nylon rope } 4, \\
\text { light } 3 \text {, mat } 2, \\
\text { fire cylinder5, } \\
\text { hammer2, } \\
\text { Carrabin screw8, } \\
\text { crowbar, chest } \\
\text { harness2,prime bar } \\
\text { 1, pump 2, tarpaulin } \\
\text { 1, swimming jacket } \\
\text { 10, gal 5, plastic } \\
\text { bucket } 3 \text {, plastic jug } \\
8 \text {, whistle } 7 \text {, rain } \\
\text { suit } 2 .\end{array}$ & & & & $\begin{array}{l}\text { buckets } 10 \text {, pump } 3 \text {, } \\
\text { hand mike } 4 \text {, rope } 8 \\
\text { roles, torch light } 2 \text {, } \\
\text { gloves } 10 \text { pairs, fire } \\
\text { distinguisher8, tarpaulin } \\
\text { medium } 2 \text {, tarpaulin } \\
\text { small } 12 \text {, tarpaulin big } \\
3 \text {, mattress } 78 \text {, whistle } 1 \text {, } \\
\text { head light } 15 \text {, non-food } \\
\text { relief items } 14 \text { packets, } \\
\text { jugs } 25 .\end{array}$ \\
\hline
\end{tabular}

Source: DPRP, 2019 
Nepal Red Cross Society (NRCS) also has their own search and rescue materials. NRCS provides their material to district disaster management committee (DDMC) with the trained human resources at the time of emergency response. NRCS has their own warehouse in the district to store non-relief material including search and rescue materials. It does not seem to have coordination between community and security forces regarding the search and rescue. So, this need to be extended the coordination in the days to come.

Table 5: List of search and rescue material in NRCS

\begin{tabular}{|r|r|r|r|r|r|r|r|r|}
\hline \multicolumn{7}{|c|}{ Rescue materials } \\
\hline Stretcher & Rope & Tent & Helmet & Stick & Crutches & $\begin{array}{c}\text { Family } \\
\text { pack }\end{array}$ & Bucket & $\begin{array}{c}\text { Gum } \\
\text { boot }\end{array}$ \\
\hline 24 & 50 & 5 & 32 & 13 & 11 & 25 & 100 & 8 \\
\hline
\end{tabular}

Source: Field Survey, 2019

NRCS has 24 stretchers, 50 quills of rope, five tents, 32 helmets, 13 sticks, 11 crutches, non-relief items for 25 families, 100 buckets and eight pairs of boots. Stick and crutches store to support for person with disability and who got injure at the time of disaster. Except these, there are 10 community disaster risk management committees in the adjoining villages of Mahakali river where there are also placed 10 sets of search and response kits with 144 trained human resources. There is lack of search and rescue materials management plan and utilization guideline in the district.

\section{Capacity on heavy equipment and emergency transportation}

If there is large scale of disaster like flood, landslides and specially earthquake, heavy equipment need to alert for search and rescue purpose. Heavy equipment is supportive to move the heavy materials of house, schools, hospitals, road. This is also useful to rescue for the multi store buildings at the time of emergency.

Table 6: Capacity on heavy equipment and emergency transportation

\begin{tabular}{|l|r|l|}
\hline \multicolumn{1}{|c|}{$\begin{array}{c}\text { Mechanical } \\
\text { property }\end{array}$} & Number & \multicolumn{1}{|c|}{ Places } \\
\hline Excavator & 14 & Different parts of district \\
\hline Backhoe loader & 14 & Different parts of district \\
\hline Tripper & 13 & Different parts of district \\
\hline
\end{tabular}




\begin{tabular}{|l|r|l|}
\hline Ambulance & 7 & $\begin{array}{l}\text { Red Cross district chapter, Red cross sub chapter } \\
\text { Jogbudha, Sub regional hospital, Ganyapdhura } \\
\text { rural municipality ward no. 1 and Nabadurga rural } \\
\text { municipality }\end{array}$ \\
\hline Fire brigade & 2 & Amargadi and Parshuram municipality \\
\hline
\end{tabular}

Source: Field Survey, 2019

Dadeldhura district has 14 excavators, 14 backhoe loaders and 13 trippers. These all are from the construction companies. There are total seven ambulances. Out of seven few need to be repaired. According to the population of the district, the number of ambulances is very few. Each rural municipality should have one ambulance for emergency health service. There are only two fire brigades in Dadeldhura (Table 6)

\section{Conclusion}

Dadeldhura is one of the disaster-prone districts of Nepal. Particularly, due to the Mahakali river and its tributaries, people who live nearby to river and hill area are highly vulnerable. For ages community has lost human and physical assets at the time of monsoon. According to the resources and disaster response plan, Dadeldhura district has moderate level of capacity for disaster response on search and rescue. Nepal government has national disaster response framework (NDRF) that provides the outline of disaster response. Dadeldhura district has district disaster management plan that updated the major hazards, cluster capacity and gap. Nine clusters have formed and updated emergency response plan. It is better to have at least a rescue team in a village. Generally, eight people consists in a team of search and rescue in Nepal. So, the number of search and rescue trained people need to be increased. likewise, there need to be increased the facility of ambulance and fire brigades in each rural municipality. Existing ambulance need to be repaired and maintained regularly.

It is necessary to have a separate fund to recover and replace the used of search and rescue materials. it is recommended to develop the search and rescue materials management plan and utilization guideline in district level. All the disaster affected people cannot spend the money for ambulance service so that DDMC needs to take lead to manage free service. The existing capacity is not enough to disaster response so, new DPRP has to be updated with new activities to enhance the capacity. 
Raj Kumar Pariyar \& Basanta Kumar Neupane / Major hazards and disaster ... Vol. 13: 201-212, 2020

\section{References:}

Shongjog Multi-stakeholder Platform (2017). Communication with communities in disaster emergency response and recovery: Volunteers guideline. Bangaladesh. Publisher

DFID (1999). The sustainable livelihood framework. London: DFID

DFID (2004). Disaster risk reduction: a development concern: A scoping study on links between disaster risk reduction, poverty and development. London: DFID

DAO (2018). District disaster preparedness and response plan. Dadeldhura: District Administration Office (DAO).

DEO (2019). Introduction about Dadheldhura district. http://www.deodadeldhura.gov. $\mathrm{np} /$ content/About.

Ghimire, L. M., \& Basnet, L. (2015). Land use and land cover change in the churia-tarai region, Nepal. http://chureboard.gov.np/wp-content/uploads/2015/06/Landuse-and-Land-cover-change-in-the-Churia-by-Moti-Lal-Ghimire-Ph.D.pdf.

IFRC (2017). Emergency response policy. https://media.ifrc.org/ifrc/wp-content/ uploads/sites/5/2017/07/emergency-policy_EN.pdf.

Koka, M. P., Sewa, R. H., Mbaya, K. R., Kilindimo, S. S., Mfinanga , J. A., Mwafongo, V. G., Wallis, L. A., \& Reynolds, T. A. (2018). Disaster preparedness and response capacity of regional hospitals in Tanzania: a descriptive crosssectional study. https://doi.org/10.1186/s12913-018-3609-5.

MoFAGA (2017). Local disaster and climate resilience planning guidelines (LDCRP guidelines-2074). Kathmandu: Ministry of federal Affairs \& General Administration (MoFAGA).

MoHA (2009). Nepal disaster report 2009. Kathmandu: Government of Nepal, Ministry of Home Affairs.

MoHA (2015). Nepal disaster report 2015. Kathmandu: Government of Nepal, Ministry of Home Affairs.

MoHA (2017). Nepal disaster report 2017. Kathmandu: Government of Nepal, Ministry of Home Affairs.

MoHA (2019). Nepal disaster response framework. Kathmandu: Government of Nepal, Ministry of Home Affairs.

MoHA (2016). Terminology on disaster risk reduction. Kathmandu: Government of Nepal, Ministry of Home Affairs. 
MoLD (2010). Local disaster risk management planning guideline (LDRMP). Kathmandu: Government of Nepal, Ministry of Local Development.

Osti, R. (2008). A feasibility study on integrated community-based flood disaster management of Banke district, Nepal phase 1(a): baseline study. International Centre for Water Hazard and Risk Management (ICHARM), Public Works Research Institute (PWRI) and Nepal Development Research Institute (NDRI).

Proaga, V. (2014). The concept of vulnerability and resilience. https://www.sciencedirect. com/science/article/pii/S2212567114009526

UNHCR (2019). Emergency Handbook. Place of Publication. UNHCR

UNISDR (2009). UNISDR Terminology on disaster risk reduction. Geneva, Switzerland: United Nations International Strategy for Disaster Reduction (UNISDR). 